\title{
縦隔内気管損傷の手術例の検討
}

\begin{tabular}{|c|c|c|c|c|c|c|c|}
\hline & 藤田保健徫 & 大学胸部外 & 同短其 & 学専 & 攻科* & & \\
\hline 部 & 良 信 & 入 山 & 正 & 渡 & 辺 & 浩 & 次* \\
\hline 木 & 浩 路 & 山 下 & 満 & 武 & 田 & & 功 \\
\hline 、村 & 裕 志 & 山 本 & 徹 & 金 & 子 & & 完 \\
\hline
\end{tabular}

\section{Intrathoracic Tracheal Injury}

Yoshinobu HATTORI, Tadashi IRIYAMA, Kouji WATANABE*

Kouji NEGI, Mitsuru YAMASHITA, Isao TAKEDA

Hiroshi, SUGIMURA, Tooru YAMAMOTO

Kan KANEKO and Shuichiro SUGIMURA

Department of Thoracic Surgery, Fujita Health University School of Medicine.

Fujita Health University College*.

5 例の縦隔内気管損傷の手術経験を得たので考察を加えて報告した。症例 1 は43歳, 男性。乗用車で電柱に衝 突し受傷した。気管分岐部中枢側の不完全断裂で, 右後側方開胸で損傷部を端々吻合した。症例 2 は51歳, 男性。 乗用車で電柱に衝突し受傷した。中部気管の不完全断裂で, 胸骨正中切開で損傷部を端々吻合した。症例 3 は63 歳, 男性。建築機械に胸部を挾まれ受傷した。気管分岐部中枢側の膜様部裂創で, 右後側方開胸で損傷部を直接 縫合した。症例 4 は58歳, 女性。気管支喘息重積発作による人工呼吸器管理中に発生した気管分岐部中枢側の模 様部裂創で, 右後側方開胸で損傷部を直接縫合した。症例 5 は 56 歳, 男性。下咽頭腫瘍で喉頭全摘食道再建術中 に, 縦隔内気管の膜様部を損傷し, 仰臥位右前方腋窩開胸で損傷部を直接縫合した。 5 例とも修復術後の縫合不 全や狭窄もなく治癒したが，症例 4 は術後 2 カ月で喘息による呼吸不全で死亡した。

索引用語：縦隔内気管損傷 (Intrathoracic tracheal injury), 鈍的損傷(Blunt trauma), 気管支鏡検查 (Bronchoscopy)

\section{はじめに}

縦隔内気管損傷は遭遇することが比較的稀な疾 患であり，その治療法にはいまだ困難な点がある。 当科では現在までに 5 例の縦隔内気管損傷の手術 経験を得たので，考察を加えて報告する。

症例 $1 ： 43$ 歳, 男性。

乗用車で電柱に激突して受傷した。近医で右股 関節脱臼骨折の整復を受けたが, 呼吸困難と皮下
気腫が増悪したので, 受傷当日に当科に転院した。 入院時の胸部X線写真では, 血気胸は認めなかっ たが，縦隔および深頝部の著明な気腫を認めた。 気管支鏡検查で，気管分岐部から中枢側の $3 ， 4$ 気管軟骨輪が損傷し，内腔に突出しているのを認 めたので，同日に緊急手術を施行した(Fig. 1)。 右後側方第 4 肋間開胸し，術野扦管による呼吸管 理を行った。損傷部を $3-0 \mathrm{Vicrl}{ }^{\circledR の}$ 全層結節縫合 で端々吻合した。術後は吻合部の狭窄もなく軽快 


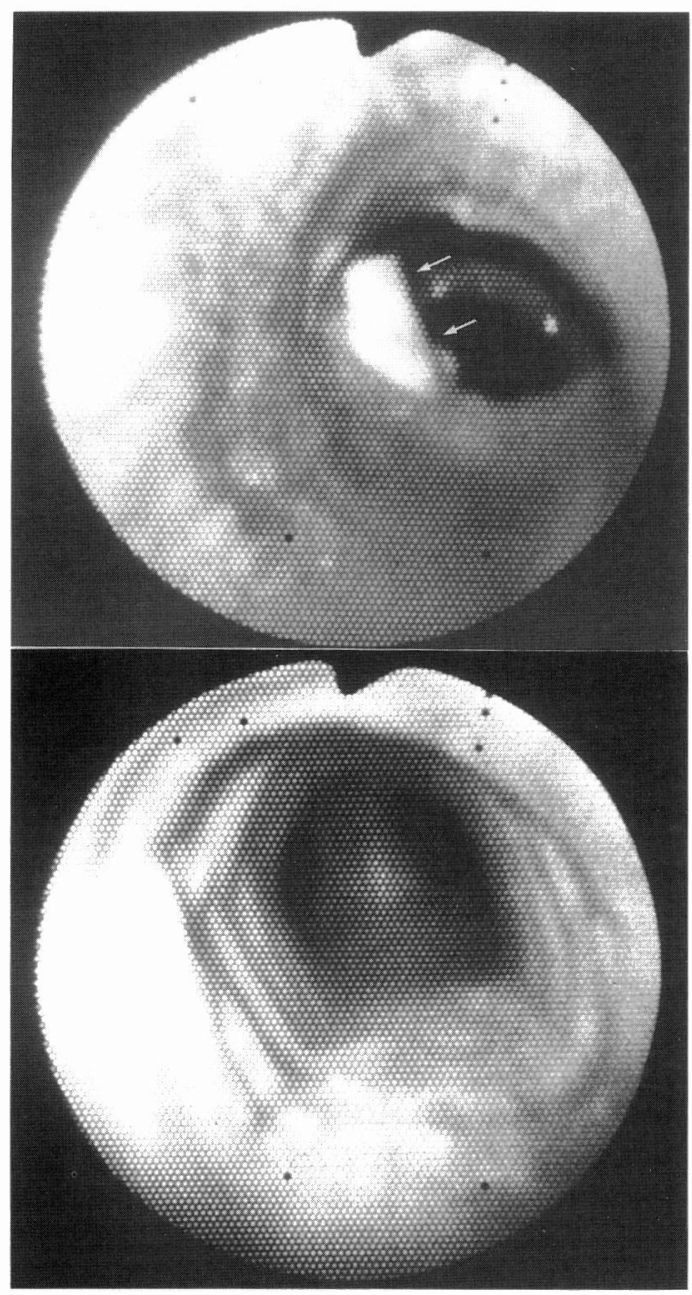

Fig. 1 Bronchoscopies in case 1 revealing disruption of the fourth and fifth rings above the carina on admission (top) and complete healing 2 months after operation (bottom).

\section{退院した（Fig. 1)。}

\section{症例 2：43歳, 男性。}

乗用車で電柱に激突して受傷し，意識障害のた め当院脳神経外科に入院した。呼吸困難のため気 管切開が施行されたが，呼吸困難は改善されず， 皮下気腫が増悪したので，受傷当日に当科に紹介 された。入院時の胸部X線写真では, 左多発胁骨骨 折と血気胸と, 縦隔㧍よび深颈部の著明な気腫を 認めた。気管支鏡検查で，気管分岐部から $5 \sim 6$ cmの中枢側の気管軟骨の損傷を認めた (Fig. 2) ので，同日に緊急手術を施行した。気管支鏡下に

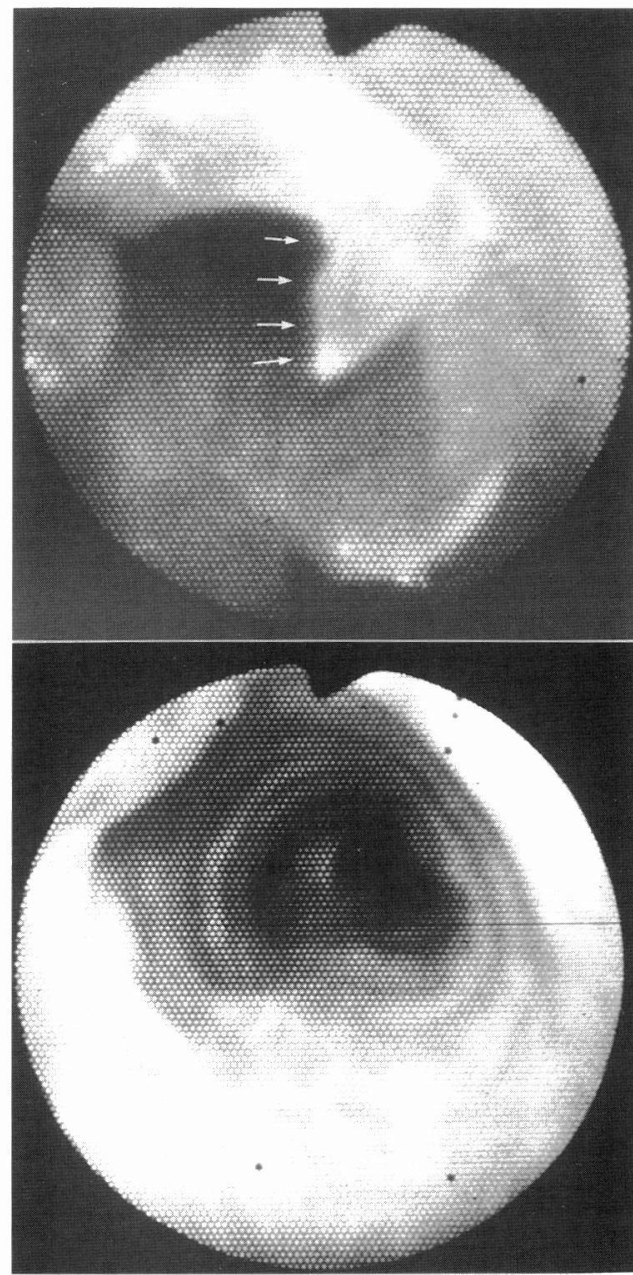

Fig. 2 Bronchoscopies in case 2 revealing disruption of the trachea 5-6 cm above the carina on admission (top) and complete healing 2 months after operation (bottom).

経口挿管し，気管切開口を閉鎖し，胸骨正中切開 にて術野挿管し, 断裂部を 2-0 Vicrl ${ }^{\circledR} の$ 全層結節 縫合で端々吻合した。術後は吻合部の狭窄もなく 軽快退院した（Fig. 2)。

症例 $3: 63$ 歳, 男性。

大型鉄製機械に胸部を挾まれて受傷し，当科に 搬送された。入院時の胸部X線写真と胸部CTで主 気管支から分岐部にかけて縦隔気腫を認めた

(Fig. 3)。気管支鏡検䍒で，気管分岐部の 1 気管 軟骨中枢側から口側へ 4 気管軟骨輪の模様部裂創 を認めた (Fig. 3)。受傷 3 日目，ダブルルーメン 

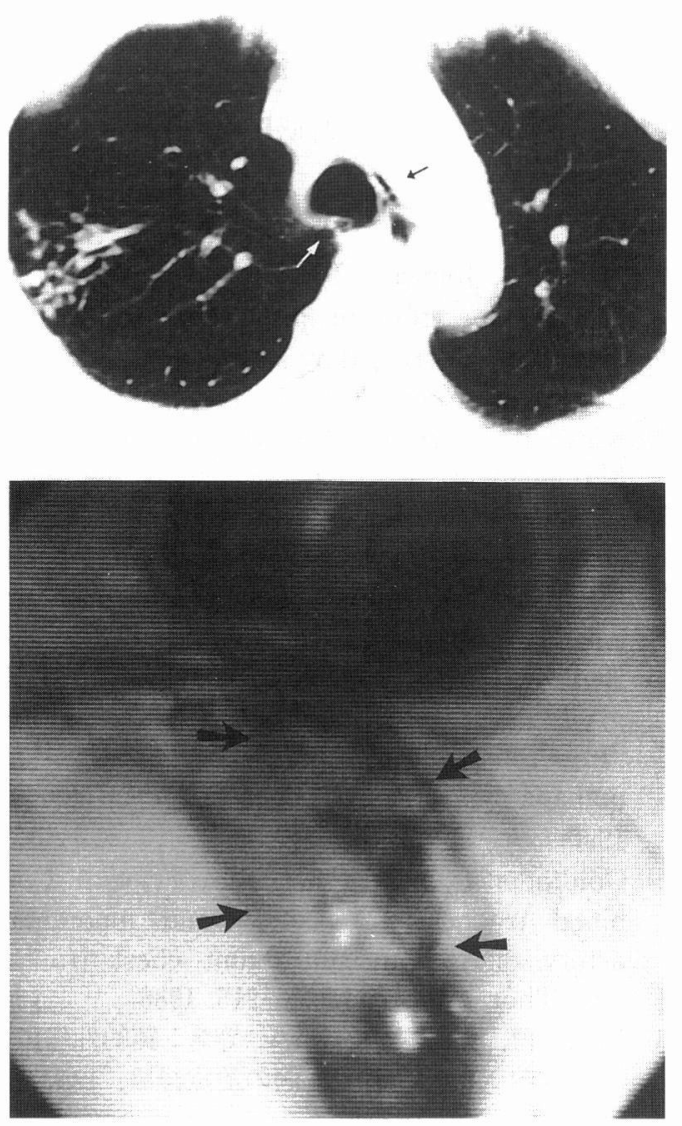

Fig. 3 CT on admission (top) in case 3 showing tracheal disruption (white arrow) and mediastinal emphysema (black arrow) and bronchoscopy perfomed on the third day revealed laceration of membranous portion from the 6 th to 2 nd ring above the carina (bottom).

チューブを㨂管し，右後側方第 4 肋間開胸で手術 を施行した。裂創部を 5-0 Maxon ${ }^{\circledR} の$ 結節縫合で 直接閉鎖した。術後は吻合部の狭窄もなく軽快退 院した。

\section{症例 $4: 58$ 歳, 女性。}

気管支喘息重積発作のため插管し，人工呼吸器 管理開始 3 週間後に，気管内出血を認めた。気管 支鏡で気管分岐部中枢側の模様部裂創を認めた

(Fig. 4)。右後側方第 4 肋間開胸したが，片肺換 気は困難であった。両肺換気で損傷部を 4-0 PDS II ${ }^{\circledR} の$ 結節縫合で直接閉鎖した。術後損傷部 は問題なかったが，人工呼吸器から離脱できず,

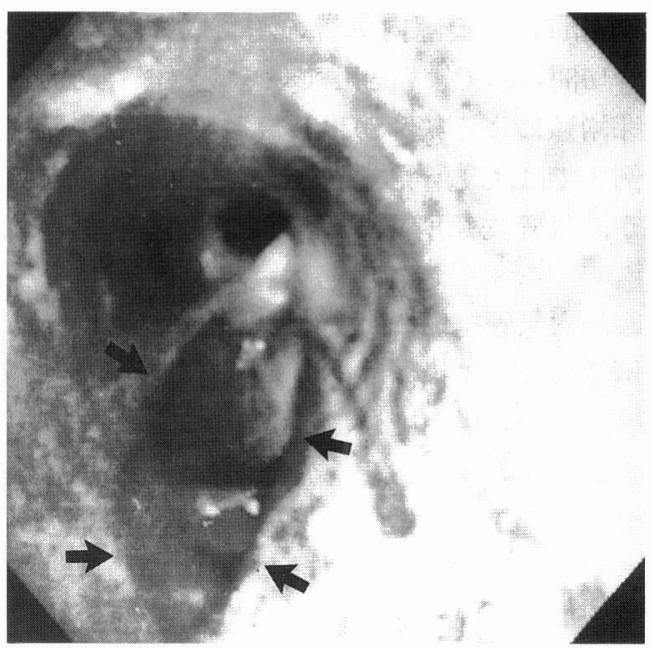

Fig. 4 Bronchoscopy in case 4 revealing laceration of membranous portion above the carina.

喘息による呼吸不全で 2 力月後に死亡した。

症例 5 : 56歳, 男性。

下咽頭腫瘍で喉頭全摘と気管切開を施行し，食 道を剝離中に気漏が出現した。縦隔内気管損傷と 判断し，仰臥位のまま右前方腋窩切開し，第 4 肋 骨を切除し開胸した。損傷部は分岐部より $3 \sim 4$ 気管軟骨輪の模様部であった。右片肺插管で損傷 部を 4-0 PDS II ${ }^{\circledR} の$ 結節縫合で直接閉鎖した。術 後膿胸を合併したが，軽快退院した。

\section{考察}

縦隔内気管損傷は，1）直達力（鋭的，直接圧 迫など，，2）分岐部への張力による牽引， 3 ）気 道内圧の急激な上昇，4）医原性などにより発生 する ${ }^{122) 31}$ 。鈍的外傷による胸腔内気管損傷は, 早期 の診断と適切な治療が重要である。胸部単純X線 写真で深頝部および縦隔気腫を認めれば，本症を 疑い気管支鏡を施行すべきであるが，損傷部位を 見逃したり，過小評価したりすることがあり，必 ずしも損傷の診断ができるものではない2233。 Baumgartnerらによれば気管損傷が初回の気管 支鏡で診断されたのは 3 例中 2 例であり，熟練社 に上る実施が望まれる4)。隣接する臟器 (食道, 心・ 血管）の損傷の有無についても，治療方針を決定 するうえで極めて重要であるので，確認する必要 がある115) 
Kirshら ${ }^{2}$ は縦隔内気管の小さな裂創であれば 気管切開のみでよいとしているが, 保存的治療で 肉芽増殖による狭窄が生じたとの報告もある6)。 症例 3 では,CT所見で損傷は小さいものと思われ たが，気管支鏡所見により早期の手術を施行し た7)。

縦隔内気管損傷に対する手術の到達方法には, 症例 2 のように損傷部位が上縦隔であったり，心 血管損傷の合併が疑われる場合には, 胸骨正中切 開を選択すべきであり，症例 $1 ， 3$ ，や 4 のよう に分岐部近傍の損傷には, 右後側方開胸を選択す べきである2)4778)9910)11)。症例 5 は術中の合併症で あり，仰臥位のまま腋窩前方開胸で手術を行った が，視野は比較的良かった。

術中の気道確保の方法には, 術野からの插管, 気管内チューブの気管支内挿管, ダブルルーメン チューブによる挿管, 高頻度換気法等があ る21512)。いずれの方法を用いるにしても損傷部位 を良く考慮して選択する必要があり，片肺換気が 困難な症例もあるので, 麻酔科と連係を取り適切 に管理することが重要である。

損傷部位のデブリドメントが必要かどうかに関 しては諸説があるが過度の剥離は避けるべきであ る9)。また, 縫合系に関しても, 吸収糸を用いるか, 非吸収糸を用いるに関しても意見が分れ

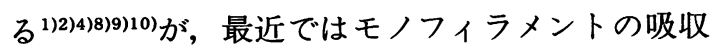
糸が好まれている210111。われわれは 5 例ともデブ リドメントは施行せず，吸収系による結節縫合を 行ったが, 全例修復部の縫合不全や狭窄は認めな かった。

術後管理については，可及的早期に抜管するよ うにし，修復部に陽圧がかからないようにする。 喀痰吸引の際には縫合部への機械的損傷を避ける よう細心の注意が必要であり，気管支鏡を用いた 吸痰は最も効果的である。症例 4 は術後も長期に 挿管を必要になったが, low pressure cuff気管の チューブを用いることで, 合併症の発生もなく治 癒した。

\section{結語}

縦隔内気管損傷の 5 例の手術経験を得たので,
縦隔内気管損傷の診断方法, 到達方法, 修復方法 について考察した。5例とも修復術後の縫合不全 や狭窄もなく治癒し，4例は退院したが，1例は 術後 2 カ月で喘息による呼吸不全で死亡した。

\section{参考文献}

1) Mills SA, Johnston FR, Hudspeth AS, et al : Clinical spectrum of blunt tracheobronchial disruption illustrated by seven cases. J Thorac Cardiovasc Surg 84 : 49-58, 1982

2) Kirsh MM, Orringer MB, Behrendt DM, et al : Management of tracheobronchial disruption secondary to nonpenetrating trauma. Ann Thorac Surg $22: 93-101,1976$

3) Roxburgh JC: Rupture of the tracheobronchial tree. Thorax $42: 681-688,1987$

4) Baumgartner F, Sheppard B, de Virgilo C, et $\mathrm{al}$ : Tracheal and main bronchial disruptions after blunt chest trauma: Presentation and managament. Ann Thorac Surg $50: 569-574$, 1990

5) Goldfaden D, Seifert P, Milloy F, et al:Combined tracheal transection and innominate artery disruption from blunt chest trauma. Ann Thorac Surg $41: 213-215,1986$

6) 山元 博, 桜井純一, 橒木 等他: 鈍的外傷に伴 う胸腔内気管断列の 2 症例の治療経験. 日胸外会 誌34：886-891，1986

7）入山 正, 杉村修一郎, 服部良信他：鈍的外傷に よる縦隔内気管損傷の 1 例。 日呼外会誌 $10 ： 813-$ 816, 1996

8) Rossbach MM, Johnson SB, Gomez MA, et al: Management of major tracheobronchial injuries: A 28-year experience. Ann Thorac Surg $65: 182-186,1998$

9) Martinez MJ, Colonel L, Hotzman RS, et al : Successful repair of transected intrathoracic trachea after chest trauma. J Thorac Cardiovasc Surg $91: 307-314,1986$

10) Taskinen SO, Salo JA, Halttunen PEA, et al: Tracheobronchial rupture due to blunt chest trauma : A follow-up study. Ann Thorac Surg $48: 846-849,1989$

11) Barmada H, Gibbons JR,: Tracheobronchial injury in blunt and penetrating chest trauma. Chest $106: 74-78,1994$

12）佐藤良智, 今泉恵次, 中沢 聡：鈍的外傷による 気管分岐部断裂一緊急手術による救命例一. 日胸 外会誌34：268-276, 1988 